\title{
Seasonal variation in the selective behaviour of dairy goats on the Sierra area of spain
}

\section{Sánchez-Rodriguez ${ }^{1}$, A.G. Gómez-Castro ${ }^{1}$, E. Peinado-Lucena ${ }^{2}$, M. Mata-Moreno ${ }^{1}$ and V. Domenech-Garcia ${ }^{1}$}

1) Department of Animal Production, University of Cordoba, Veterinary Faculty

$\left.{ }^{2}\right)$ Cattle Feed Production Unit, Institute of Zootechnics

Medina Azahara 9, 14005 Córdoba, Spain

(Received 18 March 1993; accepted 18 May 1993)

ABSTRACT

Seasonal variation in the preference of a herd of dairy goats when grazing grass, trees and shrubs or acorns was studied. Grass accounted for $70 \%$ (1478 mouthfuls), $76 \%$ (4221 mouthfuls) and $65 \%$ (2228 mouthfuls) of the selections made in the autumn-winter, spring and summer seasons, respectively, which showed a close relationship between palatability and degree of maturing of available grass. Ligneous species (trees and shrubs) were consumed to variable extents during the year, their consumption gradually increasing between autumn-winter, spring and summer, and accounting for 19\% (395 mouthfuls), $24 \%$ (1303 mouthfuls) and 35\% (1219 mouthfuls) in the three seasons, respectively. This increase was also a result of the decreasing availability of grass in the natural course of the seasons. Despite availability in autumn-winter period, holm and cork oak acorns only accounted for a small percentage in the overall ration (11\%,221 mouthfuls). The results revealed the importance of the herbaceous components within the total goat ration, goats using woody browse only when there was grass shortage.

KEY WORDS: palatability, caprine, shrubs, trees, grazing, browsing

\section{INTRODUCTION}

Herbivores, which feed on feedstuffs of widely variable quality, must match their nutritive needs and intake rates to the varying conditions of pasture (Pfister and Malecheck, 1986). The diet they choose is dictated by a number of factors among which those features of plants which determine their palatability, play a major role (Ramirez et al., 1991).

Along with grass in goat diets, brush plants can constitute an important source of feed in semiarid regions (Wilson, 1977; Morrical, 1984; Pfister and Malecheck, 1986; Schacht and Malechek, 1989), supplying essential proteins (Mangan, 1988), although Le Houerou (1980) maintains that the energy supplied from brush is scant, does not fill cattle needs, but can be important for goat production. 
The west and southwest of Spain has a grazing area around 5700000 ha, but there are few reports on the grazing behaviour of goats, and none dealing with the mountain areas north of Córdoba, Seville and Huelva, where typical Mediterranean vegetation grows at different stages and with a variable degree of human participation.

This work aimed to determine the basic spectrum of goat diets throughout a grazing cycle on areas of the Northern Sierra of Seville.

\section{MATERIAL AND METIIODS}

A herd of 220 Florida dairy goats, of $60 \mathrm{~kg}$ live weight, was used. Goats were farmed semiextensively. and received a feed supplement of $0.66 \mathrm{~kg}$ barley/day/goat in summer, autumn and winter. Milk production was $432 \mathrm{~kg}$ (3.22\% protein and $4.84 \%$ fat) in 216 days of lactation, and one kid was produced per litter. Goats were 4 to 8 years old. Since there were three kidding periods (March, September, December), the herd comprised animals at different stages of milk production. Florida is a hypermetric, longilineal and cyrtoid dairy breed native to the Guadalquivir Valley, located in the province of Seville, where there is an estimated population of 30000 breeding goats, used primarily for milk and cheese production. One of the main characteristics of this breed is its ability to utilise natural resources and agricultural residues in grazing (Sánchez et al., 1990).

Feeding behaviour was monitored on one day per week over the whole grazing season, using six adult females previously selected as representative of their herd (Meuret et al., 1985). Each animal was observed for a ten-minute period. Monitoring began each day with the animal nearest the observer, and continued with the remaining animals at ten-minute intervals (the time necessary to locate and approach the animals). When all experimental animals had been monitored once, the process was repeated in two more monitoring shifts, always beginning with the same animal. In this way, minitoring covered $50 \%$ of grazing time with three observation periods per animal. The species used, and the number of mouthfuls taken, were recorded.

The study area was located in the Sierra Norte in the province of Seville (Spain), at $500-700 \mathrm{~m}$ above sea level (lat. $37^{\prime \prime} 56^{\circ} \mathrm{N}$; long. $5^{\circ} 28^{\prime} \mathrm{W}$ ). Mean annual rainfall is $800 \mathrm{~mm}$; the mean winter temperature $7.5^{\circ} \mathrm{C}$ (minimum $-9^{\circ} \mathrm{C}$ ) and the mean summer temperature $22.9^{\circ} \mathrm{C}$ (maximum $38^{\circ} \mathrm{C}$ ). The area consists of mixed holm oak-cork oak ranges with areas of shrub cover containing abundant Cisfus spp. Weight per bite was recorded for all grassy species and for the following woody species. Quercus rotundifolia Lam., $Q$. suher L., Olea europaea L., Cistus salvifolius L., C. albidus L., C. ladanifer L., Pistacia lentiscus L. and P. terebinthus L. However, we did 
not control others such as $Q$. faginea Lam., Arbutus unedo L., Phyllirea angustifolia L., C. monspeliensis L., C. populifolium L. or Ulex europaeus L. which, though palatable, accounted for rather a small proportion of the goats diet (less than $0.1 \%$ ), consistent with earlier findings by Harrington (1978) and Rios and Riley (1985), who pointed out that, although goats may consume a large variety of species, most of their diet consists of the $3-8$ most common species in the grazing area.

GRASS

Grass intake per bite was quantified by grouping all herbaceous species in a single class according to Hoppe et al. (1977), Bourbouze (1980) and Bryant et al. $(1979,1980)$. Weight per mouthful was estimated by manual simulation of grazing using the hand clipping method as described by Meuret et al. (1985) by dividing the weight of samples collected at five different places into the number of bites (500). Samplings were carried out with a variable frequency depending on the vegetative status of the grass and the evolution of animal behaviour. A single sample was considered to be representative of November, December and January, and another of July and August. The greater dynamism of the herbaceous stratum and animal grazing compelled us to carry out monthly samplings between January and July. Data were subjected to variance analysis at the Computer Centre of the Institute of Zootecnics.

\section{TWIGS}

Amounts of arboreal and shrubby species ingested by goats were estimated individually as, unlike herbaceous species, their browsing depends on the vegetative status of the plants. A method was developed based on the marked correlation between twig weight and diameter, which was investigated in our department by Tovar Andrada (1978) and Martinez Teruel (1984).

Regression equations were fitted for each control on the basis of about 200 weight and diameter measurements by using material of each species colleted at the grazing spots. Potential relation was used, because this type was the most accurate in accounting for weight-diameter relations in all species and control dates, consistent with findings by Rumble (1987).

Stem diameter at the biting point (DBP) as an independent variable in the fitted regression equations for each ligneous species and sampling season were used to calculate the weight of a bite. DBPs were obtained for each control by a group observers who followed the herd and measured diameters of the browsed stems according to directions given by Tovar Andrada (1978). In both cases, diameters were measured to within $0.05 \mathrm{~mm}$ with a slide calliper and weights to 
within $0.01 \mathrm{~g}$ on an electronic balance. Data were subjected to variance analysis at the Computer Center of the Institute of Zootecnics.

\section{RESULTS AND DISCUSSION}

Table 1 reflects the variation in preferences by goats for each of the main feed groups making up their diet. All of these variations are significant $(P \leqslant 0.05)$ except for the ligneous-acorn comparison, which did not differ in the autumn-winter period. As far as seasons are concerned, the significance for grass was $P \leqslant 0.01$, except for comparing the autumn-winter period with summer $(P \leqslant 0.005)$. The ligneous species had the same significant differences, except between spring and summer $(P>0.005)$. The significance of acorns was $P \leqslant 0.001$. Goats chose grass preferentially over ligneous species throughout the periods (Tables 1 and 2), consistent with findings of Schwartz and Said (1981) while Arnold and Dudzinski (1966) found that the most abundant species are also those consumed preferentially.

The relationship between the selection of grass and its seasonal production was virtually linear throughout the winter-spring period, it decreased over the

TABLE I

Average number of mouthfuls and statistical differences between the different strata and seasons

\begin{tabular}{lrrrr}
\hline Season & \multicolumn{1}{c}{ Grass } & Trees and shrubs & Acorns & Total \\
\hline Autumn-winter & ${ }^{\mathrm{a}} 1478.1 \pm 103.4^{\mathrm{a}}$ & ${ }^{\mathrm{a}} 394.5 \pm 48.1^{\mathrm{b}}$ & ${ }^{\mathrm{a}} 220.6 \pm 27.3^{\mathrm{b}}$ & ${ }^{\mathrm{a}} 697.7 \pm 105.3$ \\
Spring & ${ }^{\mathrm{b}} 4221.1 \pm 363.2^{\mathrm{a}}$ & ${ }^{\mathrm{b}} 1302.9 \pm 138.7^{\mathrm{b}}$ & ${ }^{\mathrm{b}} 15.0 \pm 4.5^{\mathrm{c}}$ & $\mathrm{b}^{\mathrm{b}} 1846.3 \pm 132.5$ \\
Summer & ${ }^{\mathrm{a}} 2228.7 \pm 358.7^{\mathrm{a}}$ & $\mathrm{b}_{12} 1219.5 \pm 275.7^{\mathrm{b}}$ & - & ${ }^{\mathrm{b}} 1724.1 \pm 112.3$ \\
Total & $2642.6 \pm 258.3^{\mathrm{a}}$ & $972.3 \pm 122.6^{\mathrm{b}}$ & $117.8 \pm 25.3^{\mathrm{c}}$ & \\
\hline
\end{tabular}

The superscripts on the right and left of the figures denote the different strata and seasons, respectively. Different superscripts on the same figure denote a statistical significance of at least $P<0.05$

TABLE 2

Average per cent of number of mouthfuls and statistical differences between the different strata and seasons

\begin{tabular}{lcccc}
\hline Season & Grass & Trees and shrubs & Acorns & Total \\
\hline Autumn-winter & ${ }^{\mathrm{a}} 70.6 \pm 2.1^{\mathrm{a}}$ & ${ }^{\mathrm{a}} 18.9 \pm 2.5^{\mathrm{b}}$ & ${ }^{\mathrm{a}} 10.5 \pm 1.3^{\mathrm{c}}$ & ${ }^{\mathrm{a}} 18.9 \pm 1.9$ \\
Spring & ${ }^{\mathrm{a}} 76.2 \pm 2.9^{\mathrm{a}}$ & ${ }^{\mathrm{a}} 23.5 \pm 2.9^{\mathrm{b}}$ & ${ }^{\mathrm{b}} 0.3 \pm 0.1^{\mathrm{c}}$ & ${ }^{\mathrm{b}} 50.0 \pm 3.2$ \\
Summer & ${ }^{\mathrm{b}} 64.6 \pm 2.5^{\mathrm{a}}$ & $\mathrm{b}^{\mathrm{b}} 35.4 \pm 2.2^{\mathrm{b}}$ & - & ${ }^{\mathrm{c}} 31.1 \pm 2.1$ \\
Total & $71.5 \pm 1.6^{\mathrm{a}}$ & $26.3 \pm 2.2^{\mathrm{b}}$ & $2.2 \pm 1.2^{\mathrm{c}}$ & \\
\hline
\end{tabular}

The superscripts on the right and left of the figures denote the different strata and scasons, respectively. Different superscripts on the same figure denote a statistical significance of at least $\mathrm{P}<0.05$ 
last third of this period as a result of loss of palatability (Boza López, 1983). Hence preference and availability curves tended to diverge despite availability of pasture. Goats like sheep (Arnold, 1980) tend to be more selective in their consumption and seek only those parts of plants which grow among shrubs or in shady areas and are thus more palatable but reject the more fibrous - and hence less digestible material of already withered species (Morand-Fehr, 1982). According to our results (Table 2), grass accounted for $70 \%, 76 \%$ and $65 \%$ of the goats' rations in autumn-winter, spring and summer seasons, respectively $(P \leqslant 0.005$; Table 1). By the time grass was withered, its selection had fallen to only $60 \%$ (last summer control) and consisted basically of inflorescences of composite plants which still retained some moisture (Somlo et al., 1981). These results confirm that goats in Spain consume more grass in the wet seasons (López Palazón, 1953) and during the most intensive period of grass growth (Bryant et al., 1979), which also means a decrease in grass consumption in summer (Morand-Fehr, 1982; Meuret et al., 1985). Such a decrease can be drastic at times (from $74 \%$ to $4 \%$ in only one month) (Griego, 1977).

Ligneous species, the abundance and a vailability of which remained virtually constant, were present to a variable extent in the goats' diet selection throughout the year. Their consumption increased gradually from winter, which is indicative of greater selectivity than for herbaceous species (Malecheck and Provenza, 1983), since there are substancial variations in composition, not only in time, but also in space. The particular season therefore did determine their consumption (Damiani and De Simiane, 1980), although the vegetative stages of the plant do not condition its palability as uniformly as with herbaceous plant (Merrill, 1971). In winter (Table 2), despite scarcity of the herbaceous stratum, trees and shrubs accounted for only $19 \%$ of the goats' ration. Consumption of this group increased in spring $(24 \%)$, which can be attributed to shoots and flowers, the material typically selected in this period. In summer, its consumption rose to $35 \%$, which is consistent with the findings of Harrington (1978), who claims that the proportion of shrubs in goats' diets increases with decreasing availability of grass. This is logical since for lack of any herbaceous growth, shrubs offer forage not only in emergency, but also as quality forage since shrubs preserve their proteins, carotenes and carbohydrates better than grasses (Stodart and Smith, 1955). Although the results in this study are less than those found by other authors, the increase during the summer period was also observed by them (Meuret et al., 1985).

Holm and cork oak acorns are very palatable and actively selected by goats, particularly those fallen from trees. Therefore, periods of greatest intake of this feed group coincide with their ripening. However, despite their availability, they only accounted for a small part of the goats' diet (11\% of all mouthfuls in autumn-winter; Table 2). However, their greater unit weight must be considered 
when ingested in a single mounthful. Although there are few references to the consumption of acorns by goats, acorn tannins appear to have no adverse effect on their consumption (Morand-Fehr et al., 1983).

In summary, herbaceous components occupy a prominent place in the preferences of goats. When readily available, they can account for virtually the entire selection. Seasonal differences were singnificant, although variations were not comparable to those found by Dreyer and De Simiane (1980), who claimed that grass is the main component in goats' rations in spring and summer, while two-thirds of the intake time in the dry season are devoted to the consumption of ligneous species. Although shrubs gained increasing significance as the nutritional value of grass drops, they never reached a prominant place in the diet. Finally, the contribution of acorns was minor.

\section{REFERENCES}

Arnold E., 1980. Diet selection by aesophageal-fistulated sheep grazing in the semi-arid northern Negev (Israel). Pamphlet, Div. Sci. Publ. The Volcani Center, Bet Dagan, Israel. № 225 , pp. 110

Arnold G.W., Dudziński M.L., 1966. The behavioural responses controlling the food intake of grazing sheep. Proc. XI Inter. Grassld. Congr. Finland, Helsinki, 367-370

Bourbouze A., 1980. Utilisation d'un parcour forestier pâture par des caprins. Fourrages 82 , $121-144$

Boza López. J., 1983. Raza caprina malagueña. Contribución a su estudio etnológico y aspecto nutritivo. Alimentación de la cabra lechera. Ed. Excelentisima Diputación Provincial de Málaga, pp. 49-59

Bryant F.C., Kothmann M.M., Merrill L.B., 1979. Diets of sheep. Angora goats, Spanish goats and White-tailed deer under excellent range conditions. J. Range Manage. 32, 412-417

Bryant F.C., Kothmann M.M., Merrill L.B., 1980. Nutritive content of sheep, goats and White-tailed deer diets on excelent condition rangeland in Texas. J. Range Manage. 33, $410-414$

Damiani C., De Simiane M., 1980. Utilisation les parcours par les chèvres laitières dans les Prealpes Dromoises: approche du systeme de production. Document ITOVIC, Paris, pp. 201

Dreyer P., De Simiane M., 1980. Resultats techiniques et economiques d'un troupeau les chevres laitières utilisant des parcours. La Chèvre 120, 23-32

Griego R.R., 1977. Forage selection and nutrition of sheep and goats grazing in the Tunisian Pre-Sahara. PhD. Thesis. Logan, Utah. Utah State Univ. pp. 325

Harrington G.N., 1978. Cited by Wilson A.D. and Harrington G.N., 1980. Nutritive value of Australian browse plants. Inter. Symp. on Browse in Africa. Addis Abeba, Ethiopia, 291-297

Hoppe P.P., Qvortrup S.A., Woodford M.H., 1977. Rumen fermentation and food selection in East African sheep, goats, Thomson's gazelle, Grant's gazelle and Impala. J. Agric. Sci.. Camb. $89,129-135$

Le Houerou H.N., 1980. Chemical composition and nutritive value of browse in tropical West Africa. In: Browse in Africa. The current state of knowledge Int. Livest. Center for Africa. Addis Abeba. Ethiopia, p. $30-40$ 
López. Palazó-n J., 1953. Ganado Cabrio. Ed. Salvat S.A. Madrid, pp. 225.

Malechek J.C., Provenza F.D.. 1983. Feeding behaviour and nutrition of goats on rangelands. World Anim. Rev. 47, 38-48

Mangan J.L., 1988. Nutritional effects of tannin in animal feeds. Nutr. Res. Rev. 1, 209-216

Martínez Teruel A., 1984. Aportaciones al estudio de la biomasa arbustiva y arbórea del pastizal arbustivo mediterráneo. PhD. Thesis Fac. Vet. Univ. Córdoba, pp. 314-380

Merrill L.B., 1971. Selectivity of shrubs by various kinds of animals. In: Wildland Shrubs, their Biology and Utilization. Inter. Symp. Utah State Univ. Logan, Utah, 1971, 339-342

Meuret M., Bartiaux-Hill N., Bourbouze A., 1985. Évaluation de la consomation d'un troupeau de chévres laitiéres sur parcours forestier. Méthode d'observation directe des coups de dents. Méthode du marqueur oxyde de chrome. Ann. Zootech. 34, 159-180

Morand-Fehr P., 1982. Sistemas de producción de leche de cabra en los paises de la cuenca mediterránea. XIV Jornadas de cstudio. Economia y técnica de la producción de leche y queso de oveja y cabra. I.T.E.A. $N^{0} 1$

Morand-Fehr P., Bourbouze A., Le Houerou H.N., Gall C., Boyazogly J.G., 1983. The role of goats in the Mediterrancan arca. Livest. Prod. Sci, 10,569-587

Morrical D.G., 1984. Performance and diet quality of goat grazing creosotebush-dominated rangelands and their effects on the plant community. PhD. Dissertation. New Mexico State Univ. Las Cruces, pp. 220

Pfister J.A., Malechek J.C., 1986. The voluntary forage intake and nutrition of goats and sheeps in semi-arid tropics Northeastern Brazil. J. Anim. Sci. 63. 1078-1086

Ramirez R.G., Loyo A., Mora R., Sánchez E.M., Chaire A., 199I. Forage intake and nutrition of range goats in a shrubland in Northeastern Mexico. J. Anim. Sci. 69, 879-885

Rios G., Riley J.A., 1985. Prcliminary studies on the utilization of the natural vegetation in the Henequen zone of Yucatan for the production of goats. 1. Selection and nutritive value of nature plants. Trop. Anim. Prod. 10, 1-10

Rumble M.A., 1987. Using twigs diameter to estimate browse utilization on three shrub species in southeastern Montana. Proc. Symp. Plant-Herbivore Interactions. 172-178

Sánchez M., Herrera M., Sánchez J.A., Alvare J.J., 1990. Descripción de una nueva raza caprina (Florida Sevillana). Proc. Symp. Int. de Explotación caprina en zonas áridas. 23-26 Octubre 1990. Coquimbo Chile. Terra Arida. T. Summary p. 23

Schacht W.H., Malechek J.C., 1989. Nutrition of goats as influenced by thinning and clearing of deciduous woodland in Northeastern Brazil. J. Anim. Sci. 67, 2487-2497

Schwartz H.J., Said A.N., 1981. Dietary preferences of goats and nutritive value of forage on semi-arid pastures in, Northern Kenya. In: Nutrition and Systems of Goat Feeding. Proc. Int. Symp., Tours, France. Paris, INRA-ITOVIC. 515-524

Somlo R., Cambell G., Pelliza-Sbriller A., 1981. Study of the dietary habits of Angora goats in rangelands in Patagonia. In: Nut. et Sys. d'Álim. de la chèvre. Sym. Inter. Tours, France, p. 525

Stodart L.A., Smith A.D., 1955. Range Management. Ed. McGraw-Hill Book, N.Y. 2nd. pp. VII +433

Tovar Andrada J., 1978. Estudio experimental de la medida de la producción forrajera arbustiva. BSc. Thesis. Fac. Vet. Univ. Códoba, pp. 230

Wilson A.D., 1977. The digestibility and voluntary intake of the leaves of trees and shrubs by sheep and goats. Aust. J. Agric. Res. 28, 501-508

\section{STRESZCZENIE}

\section{Sezonowa zmienność w selektywności pobierania roślin przez kozy mleczne w górzystych rejonach Hiszpanii}

Badano zmienność sezonową w wyborze roślin (trawa, drzewa i krzewy) przez kozy mleczne podczas wypasu. Trawy stanowily 70 (1478 kęsów), 76 (4221 kęsów) i 65\% 
(2228 kęsów) paszy pobranej, odpowiednio w sezonach jesienno-zimowym, wiosennym i letnim, co wskazuje na ścisłą zależność pomiędzy smakowitością i stopniem dojrzałości dostępnej dla zwierząt trawy. Gatunki roślin o dużej zawartości ligniny (drzewa i krzewy) były zjadane w zmiennych ilościach w ciągu roku. Ich pobranie stopniowo wzrastało od okresu jesienno-zimowego poprzez wiosenny do letniego i wynosito odpowiednio 19 (395 kęsów), 24 (1303 kęsów) i 35\% (1219 kęsów). Wzrost ten był także wynikiem zmniejszającej się dostępności trawy na pastwisku podczas naturalnej zmiany pór roku. Mimo możliwości pobierania żołędzi dębu skalnego i korkowego w okresie jesienno-zimowym, ich udział w pobranej dawce wynosił zaledwie $11 \%$ (221 kęsów). Wyniki te wskazują na znaczenie paszy trawiastej w składzie paszy pobieranej przez kozy, które zjadały zdrewniałe pędy jedynie w przypadku braku trawy. 